\title{
The Importance of Citizenship, Residence and Domicile in Federal Income Taxation
}

\author{
Frank M. Keesling*
}

\begin{abstract}
A ITHOUGH the taxing power of a state encounters at its borders $A$ the taxing powers of other states and is limited by them, there is no such limitation upon the federal power. ${ }^{1}$ Notwithstanding this limitation upon the states' jurisdiction, their power to tax the local income of non-residents ${ }^{2}$ and the extraterritorial income of residents $^{3}$ has been sustained. Citizenship alone, it has been held, affords
\end{abstract}

*Member of California Bar.

1 United States v. Bennett (1914) 232 U.S. 299, upholding the power of Congress to tax property located outside the United States. At 306 the Court states: "The apphication to the States of the rule of due process rehed upon comes from the fact that their spheres of activity are enforced and protected by the Constitution and therefore it is impossible for one State to reach out and tax property in another without violating the Constitution, for where the power of the one ends the authority of the other begins. But this has no application to the Government of the United States so far as its admitted taxing power is concerned. It is coextensive with the limits of the United States; it knows no restriction except where one is expressed in or arises from the Constitution and therefore embraces all the attributes which appertain to sovereignty in the fullest sense. Indeed the existence of such a wide power is the essential resultant of the limitation restricting the States within their allotted spheres, for if it were not so then government in the plenary and usual acceptation of that word would have no existence. Because the himitations of the Constitution are barriers bordering the States and preventing them from transcending the limits of their authority and thus destroying the rights of other States and at the same time saving their rights from destruction by the other States, in other words of maintaining and preserving the rights of all the States, affords no ground for constructing an imaginary constitutional barrier around the exterior confines of the United States for the purpose of shutting that government off from the exertion of powers which inherently belong to it by virtue of its sovereignty."

2 In Shaffer v. Carter (1920) 252 U.S. 37, 54, the contention that an incone tax is a "subjective tax imposing personal liability upon the recipient of the income" and could not, therefore, be imposed upon a non-resident was renounced by the Court: "The personal element cannot, by any fiction, oust the jurisdiction of the state within which the income actually arises and whose authority over it operates in rem."

3 Lawrence v. State Tax Comm. (1932) 286 U.S. 276, upholding a tax on the income of a resident from activities in another state; New York ex rel Cohn v. Graves (1937) 300 U.S. 308, upholding the power of a state to tax the income of a resident from land in another state. In the first case, the court states, at 281, that the tax in question was "founded upon the protection afforded to the recipient of the incone by the state, in his person, in his right to receive the income, and in his enjoyment of it when received." For a discussion of this case see Keesling, The Problem of Residence in State Taxation of Income (1941) 29 CALIF. L. REV. 706, 721. 
a basis of jurisdiction for the imposition of federal income taxes." Accordingly, the power of the federal government to tax the domestic income of non-residents and aliens and the foreign income of citizens and residents cannot be challenged.

Commencing with the 1913 Revenue Act and continuing fairly consistently since, Congress has displayed an intention to make the scope of the federal income tax virtually co-extensive with its jurisdiction to tax. It is a rare and fortunate individual indeed who comes within range of the federal taxing power and escapes unscathed!

Thus citizens of the United States who also reside here, have at all times since the inception of the income tax been taxable upon their entire net income, whether derived from domestic or foreign sources. ${ }^{5}$ With the exception of a limited exemption of earned income from sources without the United States accorded by the 1926 and subsequent acts, ${ }^{6}$ no distinction has been drawn between resident and non-resident citizens. Likewise, except for the amount of credit allowable since 1928 for income taxes paid or accrued to foreign countries, ${ }^{7}$ no distinction has been inade between resident citizens and resident aliens. Accordingly, the latter are also taxable upon their entire net incoine regardless of source, whether from within or without the United States, and are allowed the same personal exemption and credit for dependents as citizens.

Although the pattern has varied somewhat, non-resident aliens have generally been taxable upon their entire income, gross or net, derived from sources within the United States. At the present, they are divided into the following three categories: ${ }^{8}$

4 Cook v. Tait (1924) 265 U.S. 47. The income tax was sustained as applied to the income from Mexican sources of a citizen of the United States who was a resident of Mexico. At 56 the Court declared: ". . . the basis of the power to tax was not and cannot be made dependent upon the situs of the property in all cases, it being in or out of the United States, and was not and cannot be made dependent upon the domicile of the citizen; that being in or out of the Umited States, but upon his relation as citizen to the United States and the relation of the latter to him as citizen. The consequence of the relation is that the native citizen who is taxed may lave domicile, and the property from which his income is derived may have situs, in a foreign county, aud the tax be legal-the government liaving power to impose the tax."

5 I. R. C. $\$ 11$, as amended by Revenue Act of 1942, 77th Cong. 2nd Sess. Pub. Law 753, c. $619, \$ 102$. U. S. Treas. Reg. 103, \$19.11-2.

6. I.C. $\$ 116(\mathrm{a})$ as amended by Revenue Act 1942, supra note 5, $\$ 148(\mathrm{a}), 26$ U.S.C. (1942) $\$ 116(a)$.

TI. R. C. $\$ 131$ (a) as amended by Revenue Act 1942, supra note 5, $\$ 158(\mathrm{a}), 26$ U.S. C. (1942) $\S 131(a)$.

8I. R. C. $\$ 211$ as amended by Revenue Act 1942, supra note 5, $\$ 106(a), 160(e)$, 26 U.S. C. (1942) §211. 
(1). Non-resident aliens not engaged in trade or business in the United States and laving a gross incoine from United States sources of $\$ 15,400$ or less. ${ }^{9}$ Individuals in this class are taxable upon their gross income at a rate of thirty per cent. They are allowed no deductions, personal exemption or credit for dependents.

(2). Non-resident aliens engaged in trade or business within the United States. ${ }^{10}$ Individuals in this class are taxable the same as citizens except that their reportable income, of course, is confined to income from sources in the United States and their allowable deductions are generally confined to items relating to such income. ${ }^{11}$ Except in the case of residents of contiguous countries, who, on a reciprocal basis, are allowed the same personal exemption as citizens, the personal exemption is limited to $\$ 500$, regardless of status, whether married, single, and so on. Credit for dependents is allowed only in the case of residents of contiguous countries. ${ }^{12}$

(3). Non-resident aliens not engaged in trade or business, having a gross income from United States sources of nore than $\$ 15,400$. In general, individuals in this class are taxable at the same rates, in the same nanner and are allowed the same deductions, exemptions and credits as individuals in (2). The reportable gross income, however, is nore restricted and the tax may in no event be less than thirty per cent of the gross. ${ }^{13}$

${ }^{9}$ I. R.C. $\$ 211(\mathrm{a})(1)(\mathrm{A})$, as amended ibid. Income from sources in the United States is defined as including interest (except interest on deposits with banks) dividends, rents, salaries, wages, premiums, annuities, compensations, remunerations, emoluments, or other fixed or determinable annual or periodical gains, profits or income. It does not include income from the sale of property in the United States whether real or personal since such income is not fixed or determinable, annual or periodical income. See U. S. Treas. Reg. 103, $\$ 19.143-2$. The exemption accorded interest received from banks presumably was inserted to encourage non-resident aliens not engaged in business here to deposit funds with American banks.

10 I. R. C. $\$ 211$ (b), as amended by Revenue Act 1942, supra note 5, \$\$160(a), 167, 26 US. C. (1942) $\$ 211(b)$. The phrase "engaged in trade or business" is specifically defined as mcluding the performance of personal services within the United States. An exception is made in the case of services performed by a non-resident alien mdividual for a non-resident ahen, a foreign partnership, or foreign corporation not engaged in trade or business here where the services do not exceed a total of ninety days and where the compensation does not exceed $\$ 3,000$. It does not include the making of transactions through resident brokers if the individual bas no office or place of business in the United States at any time during the year through which or by the direction of which such transactions are effected.

11 See U. S. Treas. Reg. 103, $\$ 19.211-7$ (c). For the limitation on deductions see I. R.C. \$213. In the case of aliens in this class, the exemption accorded interest on deposits with banks is not applicable, and gross imcome includes all incoine from sources in the United States regardless of whether it is fixed or determinable, equal or periodical income, and thus includes gains from the sale of property located here.

12I. R. C. $\$ 214$.

13 I. R. C. $\$ 211(c)$, as amended by Revenue Act 1942, supra note 5, $\$ 106(c)$, $160(\mathrm{e}), 26$ U.S.C. (1942) $\$ 211(\mathrm{c})$. The gross income is the same as in the case of individuals in Class $I$. 
Regardless of the foregoing categories, a withholding of tax at the source at the rate of thirty per cent is required in the case of payments to all non-resident aliens, with minor exceptions. ${ }^{14}$

\section{WHO ARE RESIDENTS?}

Since resident aliens are taxable upon their entire net income whereas non-resident aliens are taxable only upon income from sources within the United States, it becomes important to determine what is necessary to constitute a person a resident. Although the term is nowhere defined in the law, in Bowring v. Bowers, ${ }^{15}$ the leading case on the subject, the court affirmed that:

"An alien actually present in the United States who is not a mere transient or sojourner is a resident of the United States for the purposes of the income tax. Whether he is a transient or not is determined by his intentions with regard to the length and nature of his stay. A mere floating intention, indefinite as to time, to return to another country is not sufficient to constitute him a transient. If he lives in the United States and has no definite intention as to his stay, le is a resident. One who comes to the United States for a definite purpose which in its nature may be promptly accomplished is a transient; but if his purpose is of such a nature that an extended stay may be necessary for its accomplishment, and to that end the alien makes his home temporarily in the United States, he becomes a resident, though it may be his intention at all times to return to his domicile abroad when the purpose for which he came has been consummated or abandoned."

From the foregoing quotation, taken from the Bureau of Internal Revenue regulations, ${ }^{16}$ it is apparent that physical presence alone within the country is not sufficient to constitute one a resident. A "mere transient or sojourner" is not a resident. In the application of this rule it has been held that aliens who come to this country on specific missions which in their nature can be accomplished quickly, such as operatic and concert singing engagements, ${ }^{17}$ aliens who are admitted on temporary visas, ${ }^{18}$ even though they may be renewed

14 I. R. C. $\$ 143$ (b), as amended by Revenue Act 1942, supra note 5, \$\$108(a) (b), 160 (a) (2), 26 U. S. C. (1942) $\$ 143$ (b). The withholding rate may be reduced by treaty to not less than five per cent in the case of non-resident aliens who are residents of any country in North, Central, or South America, or in the West Indies or of Newfoundland.

15 (C. C. A. 2d, 1928) 24 F. (2d) 918, 923.

16 U. S. Treas. Reg. 103, \$19.211-2.

17 Ingram v. Bowers (D. C.N.Y., 1931) 47 F. (2d) '925.

18 I. T. $3386,1940-1$ C. B. 66 . See also Treasury Department letter dated March 24 , 1942, reprinted in 1 C. C. H. Fed. Tax Serv. $\llbracket 6297$. 
from time to time, and aliens whose stay im this country is otherwise limited by law to a comparatively short period, ${ }^{19}$ are transients or sojourners taxable as non-residents only on income from sources within the United States.

It is equally apparent, however, that an alien need not be domiciled in this country to be a resident. Presence within the country for other than a temporary or transitory purpose alone is sufficient irrespective of domicile. Thus an alien may be classed as a resident taxable upon his entire net income, both foreign and domestic, even though he retains his foreign domicile either because he has no intention of making his permanent home here or because he has no intention of abandoning his former home, both of which intentions are essential to effect a change in domicile.

This concept of residence, accordingly, represents a fine balancea middle ground-between a rule predicated solely on physical presence and the inflexible rule of domicile based largely upon subjective intentions. By the adoption of this concept, which is necessarily elastic, Congress refrains on the one hand from a harsh and impractical attempt to collect taxes on the foreign income of alien visitors. On the other hand, Congress prevents aliens who live in this country for considerable periods of time, enjoying the benefits and protection of our laws and government to the same or substantially the same extent as resident citizens, from avoiding the burden of contributing to the cost of such laws and government to the same extent as citizens, simply because they do not intend to live here indefinitely or have no intention of abandoning their previous home. ${ }^{20}$

It is axiomatic that an individual can at any one time have but one domicile and that a domicile once acquired is retained until a new one is established. Is a similar rule applicable to residence as above defined?

In connection with the exemption of foreign earned income of non-resident citizens, the Treasury Department consistently held for years that temporary physical absence alone from the United States was sufficient to constitute a citizen a non-resident during the period of absence. ${ }^{21}$ The congressional debates during the consideration of

10 G. C. M. 4236 VII-2 C. B. 131.

20 For a discussion of the difficulties that would be encountered in the collection of taxes on individuals temporarily present in the jurisdiction and of the advisability of using "residence" as distinguished from "domicile" as a basis of jurisdiction, see Keesling, op. cit. supra note 3 , at 721, 725-730.

21 Infra page 291. 
the exemption provision lend some support to this view for this particular purpose but it cannot be accepted as a general rule. Residence may not be as permanent a relationship as domicile but it is sufficiently hardy to endure throughout a temporary physical absence. Were this not so, resident aliens could easily escape the tax on their foreign income by the simple expedient of arranging to be absent from the country at the time such income is received. Congress, certainly, did not contemplate any such result.

The few rulings and cases relating to the question tend to confirm the foregoing conclusion. ${ }^{22}$ In fact, they go further and rather strongly intimate that residence once acquired is not lost until residence is established elsewhere. The individuals involved, however, had not ouly established residence, that is, been here for other than a temporary or transitory purpose, but had also become dormciled here. This circumstance probably explains the apparent extension of the domiciliary rule to residence. Such an extension appears ill founded. If presence within the country for other than a temporary or transitory purpose establishes residence, absence therefrom for other than such a purpose should terminate it, even though residence is not established in any other particular country.

It may be suggested that in determining when residence is lost a distinction should be drawn between those aliens who have only established residence in the United States and those who have also become donniciled here. In the former case it may be considered proper to hold that residence may be lost conversely to the manner in which acquired, that is, by absence from the United States for other than a temporary purpose. In the latter case it may be urged, however, that an alien should be considered a resident so long as he remains domiciled here, regardless of the length of time or the purpose for which he may be absent from this country.

Simce Congress unquestionably has jurisdiction to tax the entire income-foreign as well as domestic - of aliens who are domiciled but who do not reside here, ${ }^{23}$ failure to follow this construction would give rise to a curious hiatus in the exercise of the federal taxing power. Furthermore, discrinnination against citizens would result since, with the one exception mentioned, ${ }^{24}$ they are taxable upon their entire income even though they do not reside here.

22 O. D. 498, II C. B. 163, Appeal of Thomas (1935) 33 B. T. A. 725.

23 Supra page 284.

24 Ibid. 
The above suggestion implies, of course, that the term "resident" as employed in the Federal Revenue Act should be interpreted to include not only aliens who reside here, even though not domiciled here, as held in Bowring v. Bowers, ${ }^{25}$ but also aliens who are domiciled but who do not reside here. Such an interpretation would be as confusing as it appears. "Resident" and "residence" are already ambiguous terms. Although sometimes they have the meaning ascribed to them by the Bowring case and the Bureau's regulations, they are frequently at other times identified with domicile. In common usage "residence" and "domicile" are employed interchangeably as synonyms. To hold that at one and the saine time, residence means something different from domicile, and also means domicile would aggravate the existing confusion.

Besides, this construction seems somewhat illogical. If residence may be acquired irrespective of domicile, it should be terminable, likewise irrespective of domicile. Furthermore, since the exemption of earned incoine from foreign sources accorded non-residents is available only to citizens, a construction which would result in taxing the entire income of aliens who abandon their residence but not their domicile here, would introduce a new ${ }^{26}$ element of discrimination against them as compared to citizens. At the same time the discrimination against citizens which a contrary construction would create would be only partially eliminated. With the exception noted, citizens remain taxable on their entire income even though their domicile as well as their residence is abroad. This, of course, would not be true of aliens.

Whether, as a matter of policy, non-resident citizens who retain their domicile here should be taxed on their entire world-wide net income is an open question. The power to tax clearly exists. Although the number of such individuals is probably comparatively small, that is no reason why they should be overlooked. The collection of the tax would doubtlessly prove difficult but no inore so than in the case of non-resident citizens. On the other hand, imposition of the

\section{Supra note 15.}

26 Resident aliens are not allowed credit for foreign taxes to the same extent as citizens. The interpretation referred to, of the provision granting non-resident citizens an exemption for foreign earned income resulted in discrimination against aliens. Under this interpretation citizens were exempt from the tax on foreign earned income, if they were temporarily absent from the country for the required period of time. This of course is not true in the case of aliens who remain taxable upon their entire income including foreign earned income as long as they remain residents and, as noted, temporary absence is not sufficient to terminate residence. 
tax would result in the double taxation of the income of any such individual who has established residence in a foreign country which, like the United States, subjects residents to taxation on their entire net income.

California has met this particular problem by providing that anyone who is domiciled in the state is taxed upon his entire net income unless he has becone a resident of another state or country. ${ }^{27}$ This probably is as good a solution as can be found and might well be adopted by Congress. If adopted, provision should be made for grantimg the same exemption for foreign earned income as is accorded non-resident citizens.

In any event, whatever the solution may be, it should be achieved by legislation, not by interpretation. At the same time, suitable amendments should be enacted making it abundantly clear, on the one hand, that once residence, as distinguished from domicile, is acquired, it is retained notwithstanding temporary absences from the country, and, on the other, that it is terminated in the event of an absence for other than temporary purposes, regardless of whether residence is or is not established in any other particular country.

\section{EXEMIPTION OF FOREIGN EARNED INCOME}

In 1926 the Federal Revenue Act was amended to provide that citizens of the Umited States who are bona fide non-residents of the United States for more than six months during the taxable year should not be taxable upon earned income fron foreign sources. ${ }^{28}$ In 1942 the exemption was restricted to those citizens who are bona fide residents of a foreign country or countries during the entire taxable year. ${ }^{29}$

One might reasonably suppose that the Treasury Department would have adopted an interpretation of the term resident for the exemption provision consistent with the interpretation of the term resident as used in the provisions for the taxation of resident aliens. Thus one might have supposed that just as an alien does not cease to be a resident by virtue of temporary absence from the United States,

27 CaI. Personal Inc. TAX Act (1935) $\$ 2(\mathrm{k})$, as amended by Cal. Stats. 1937, p. 1831. For a discussion of the reasons for this provision see Keesling, op. cit. supra note 3 , at 728 .

28 I. R. C. $\$ 116$ added in 1926.

29 I. R. C. \$116 as amended by Revenue Act 1942, supra note 5, 148(a), 26 U.S.C. (1942) §116. 
the Treasury Department would have held that likewise a citizen does not cease to be a resident and accordingly does not become a "non-resident" by virtue of temporary absences and, consequently, does not obtain the benefit of the exemption, even though his temporary absences from one or more trips may amount to more than six months of the taxable year. Stated another way, one might have supposed that the Treasury Department would have held that in order to come within the exemption, a citizen must be absent for other than temporary or transitory purposes and that such absence must continue for at least six months. Such an interpretation would appear particularly appropriate in view of the use of the word "bona fide".

If one should have any such suppositions he would be greatly in error. From the very beginning the Department construed the phrase "bona fide non-resident of the Umited States" as meaning in effect "absence from the United States" regardless of the purpose of the absence, whether temporary or otherwise. ${ }^{30}$ The Department further held that the absence need not be continuous but that days, weeks and months of absence on several different trips could be counted and if they amounted in the aggregate to more than six monthis of the taxable year the citizen met the requirements of the exemption and was not taxable on income earned abroad. ${ }^{31}$ Under this interpretation citizen seamen operating on coastwise vessels, for instance, were held to be non-residents durmg the time the boats operated outside the territorial waters of the United States. ${ }^{32}$

If the interpretation accorded the term resident in the earned income exemption provision had been accorded to the same term used in the provision for taxing resident aliens, any alien physically present in the Umited States would have been considered a resident taxable upon his entire net income, even though he may have been here only on a temporary visit or vacation. Conversely, any alien who was absent from the United States would have been exempt from tax on his foreign income no matter how brief his absence and regardless of the fact he may have retained his home and intended immediately to return here. Needless to say such an interpretation of the alien taxing provisions would have given rise to an utterly chaotic situation.

${ }^{30}$ S. M. 5446 , V-1 C. B. 49 , G. C. M. 9848 , X-2 C. B. 178 , G. C. M. 12167 , XII-2

C. B. 126.

31 Ibid.

32 G. C. M. 12167, supra note 30. 
In fairness to the Department, however, it must be stated that the debates in Congress during the consideration of the exemption provision support the Department's interpretation. In answer to the question whether the exemption would affect governmental employees, Senator Smoot replied, "It does, as well as individual citizens. Sometimes their occupations keep them abroad for nine months of the year. We simply say that if they are out of the United States for six months then they are to be treated the same as if they lived in a foreign country all the time."33

Furthermore, in the reports of various Congressional Committees on the amendment, it is stated that it was the purpose thereof to increase foreign trade by exempting income of citizens while employed abroad selling our merchandise. ${ }^{34}$ Since citizen salesmen traveling abroad are frequently absent from the country only temporarily, an interpretation of the exemption provision consistent with that given to the one relating to resident aliens would have largely defeated this purpose.

In 1940 the Treasury Department endeavored to "tighten up" the earned income exemption. It did so, however, not by holding that a citizen must be absent froin the country for other than a temporary purpose to be a non-resident, but by holding that only absences for full calendar months could be counted in deternining whether the six months requirement is met. ${ }^{35}$ The ruling itself is silent as to whether it was intended to be given retroactive effect but in practice the Bureau has applied it retroactively. ${ }^{36}$

${ }^{33}$ S. M. 5446, supra note 30 . Prior to the amendment, citizens were taxable upon their entire income including foreign earned income even though they hed abroad all the time. Accordingly the statement to the effect that it was the purpose of the amendinent to place citizens absent from the country for six months in the same position as they would be if they lived in a foreign country all the time must have been based upon a misapprehension as to the scope of the law.

34 House Rep. No. 1, Ways and Means Committee and report of Conference Committee, 69th Cong. 1st Sess. (1925). See also Appeal of Bertin 1 T. C. No. 1

35 G. C. M. $220651940-1$ C. B. 100 . At 101 appears the following statement: "fractional parts of months from several trips may not be added to make whole calendar months since whole calendar months must consist of consecutive days of absence from the United States on any one trip."

${ }^{36}$ The ruling (G. C.M. 12167 , supra note 30 ) which held that temporary absence from the United States on a coastwise vessel constituted non-residence also held that compensation earned while the vessel was beyond the territorial waters of the United States constituted income from sources without the United States. This ruling remained in effect until 1940. In G. C.M. 22383 1940-2 C. B. 227, this ruling was reversed insofar as it related to sources of income. The effect of the reversal of course was to deny seamen operating on coastwise vessels the benefit of the forign earned income exemption 
A calendar month means a period of time beginning on a given day in any one month and ending on the corresponding day in the following month less one. Under the full month requirement fractional parts of a month could not be added together to make full months. Thus, if a citizen should be absent from the country three and one-half months on one trip, and two and one-half months on another trip, he would be considered a non-resident for only five, rather than six months.

Although there is no published ruling so holding, in practice Internal Revenue agents have taken the position that the full month ruling is applicable not only to citizens who are temporarily absent from the country, but also to citizens who are bona fide non-residents of the country who happen in a particular year to be here temporarily. Under this construction, if a citizen who unquestionably has been a non-resident of the country for a great number of years, perhaps for his entire life, should happen to pay a visit to this country, commencing on March 31st and ending on May 1st and then should again visit the country, commencing October 31 st and remain until December 1st, he would not be entitled to the benefit of the exemption. Under the full inonth requirement, only the months of January, February, June, July, August and September could be counted. Since these months amount to a total of six, he would not, under the ruling, be a bona fide non-resident for more than six months. Actually, of course, he would not only be absent from the country for nearly ten months but, since his presence here was only temporary, under any

since in order to come within the exemption it is necessary that the citizen be a nonresident for the specified period and also that the income be derived from sources without the United States. In I.T. 3437, 1941-1 C.B. 252, it was held that "in view of the apparent hardship which will result if G. C.M. 22383 is applied retroactively, it is the opinion of the Bureau that it should not be applied to taxable years prior to the taxable year 1940." If G. C. M. 22065 issued in 1940 which reversed the rulings in effect since 1926 holding that fractional parts of a month from several trips could be counted, should be applied retroactively then it would seem clear that the attempt in I. T. 3467 to prevent the hardship which would result from retroactively changing the rule respecting sources of income would to a large extent be nullified. This is so for the reason that probably the great majority of seamen operating on coastwise vessels would not meet the six months requirement if fractional parts of a month are not counted and hence would retroactively be denied the exemption even though the Bureau, for years prior to 1940, continued to consider that income earned on coastwise vessels is from sources without the United States. It would appear, therefore, that G. C. M. 22065 should, consistently with I. T. 3467, not be applied retroactively to years prior to 1940 . In the absence of official ruling thereon, however, local Internal Revenue agents have taken a contrary position. 
sensible construction of the term "resident", he would be a bona fide "non-resident" for the entire year.

The full month ruling appears to be an illogical restriction on an ultra liberal rule. As pointed out in Appeal of Bertin, ${ }^{37}$ which refused to follow the ruling, the cases relied upon by the Department in interpreting the term "month" have nothing to do with the question. They simply hold that in our jurisprudence the term month means the calendar month as distinguished from the lunar month. They do not hold that two half months, for example, may not be added together to inake a full month. Furthermore, there appears to be no valid reason why a citizen whose absence from the country on several trips accidentally happened to consist of seven full calendar months should be granted the exemption, whereas a citizen whose absence from the country consists of some full months and some fractional months should be denied the exemption even though his total absence might aggregate ten months or more. Certainly such a ruling would to a large extent defeat the alleged purpose of Congress-the foundation of all previous departmental rulings-to increase foreign trade by exempting incomes of citizens while employed abroad selling our merchandise!

If the ruling reflects misgivings on the part of the Department as to the wisdom of its previous liberal rulings, then consistency requires that it should abandon such rulings entirely and hold that teinporary absences, whether for full or fractional parts of a month, do not constitute one a non-resident.

In any event, regardless of whether the full month ruling is applied to citizens who are temporarily absent from the United States, it cannot be applied, with any degree of rhyme or reason, in such a manner as to make residents out of citizens who are bona fide nonresidents of the country for the entire year, simply because they are here temporarily for a portion of the year. Any attempt on the part of the Department so to do, already frowned upon by one court, ${ }^{38}$ should certainly meet with judicial disapproval.

37 Supra note 34.

38 Carstairs v. United States (E.D.Pa., 1936) Fed. Cas. No. 17522. The taxpayer was a bona fide non-resident of the United States for a number of years. During the year in question he was temporarily in the United States from January 1 to February 24 when he retumed to his country of residence where he died on July 9. Since the period of absence from February 24 to the date of death was less than six nionths, the Bureau took the position that the taxpayer did not meet the exemption requirement. The Court unequivocally held that since the taxpayer was here only temporarily he remained a bona fide non-resident from the beginning of the year until date of death. 
The 1942 amendment does not remove the uncertainty engendered by the previous rulings of the Department as to the meaning of the term "resident" for the purpose of the exemption provision. Just as the Department held that the former requirement that a citizen be a bona fide non-resident of the United States for more than six months was met by temporary absence from the United States for that period of time so the Department may hold that the requirement that a citizen be a bona fide resident of a foreign country or countries for the entire taxable year is met by being physically present in a foreign country or countries during the entire year. Such an interpretation would not be objectionable if it is applied as an extension rather than as a limitation upon the exemption provisions. After all, a year is a fairly long time and it does not appear particularly inappropriate to exempt a citizen from taxation on his foreign earned income if he is absent from the country for the entire year, even though during that time he may be in several countries and not in any one country for other than temporary purposes during the entire period. The danger of such an interpretation, however, hies in the possibility that it might be applied restrictively by requiring that a citizen must be physically present within a foreign country or countries during the entire taxable year with the result that he would be demied the exemption if he should happen to be in this country for as much as one day during the year, even though he is here temporarily and is clearly a bona fide resident of another country or countries within the ordinary meaning of the term "resident".

The requirement, that a citizen be a non-resident from the country for more than six months during the taxable year in order to obtain the benefit of the exemption, resulted in rank discrimination between those citizens whose absence from the country happened to fall within their taxable years and those whose absence overlapped their taxable years. Thus, under this provision a citizen who left the country in the latter part of May and returned in the early part of December obtained the benefit of the exemption, whereas a citizen who left in the early part of July and returned in the latter part of June of the following year was denied the exemption for both years, notwithstanding that he was absent for a period nearly twice as long.

This discrimination is not cured by the 1942 amendment which requires that a citizen must be a bona fide resident of a foreign country or countries for the entire taxable year. Under this requirement a citizen would not be entitled to the exemption even though he might 
be a bona fide resident of a foreign country for nearly two full years if his residence should commence after the beginning of one year and terminate before the close of the following year.

On occasion the Bureau has taken the position that in the case of citizens who are domiciled in community property states, the wife's share of the husband's foreign earned income does not constitute earned income from sources without the United States and, accordingly, is not exempt from tax under any circumstances. This position appears clearly incorrect and is in definite conflict with the position taken for the purpose of computing the earned income credit. ${ }^{30}$ It would appear, however, that the wife herself would have to meet the non-resident requirements regardless of whether separate or joint returns are filed. Although a wife's domicile follows that of her husband, there is no corresponding rule applicable to residence.

The extent to which citizens absent from the United States should be accorded an exemption from taxation on foreign income is of course debatable. Although non-resident citizens may possibly derive some protection from the United States not available to aliens, they clearly do not derive benefits and protection from our laws and government to the same or substantially the same extent as residents. Furthermore, it would seem that the collection of the tax on the foreign income of non-residents must be difficult and haphazard to say the least. This reasoning would tend to suggest that non-resident citizens might well be placed in the same category as non-resident aliens and taxed only on income from United States sources. On the other hand, it would appear that a resident citizen who is simply temporarily absent from the United States has no valid claim to exemption from taxation on that account. Certainly it would appear illogical to accord a resident citizen who is temporarily absent preferential tax treatment not accorded resident aliens.

These objectives could be achieved by eliminating any distinctions between citizens and aliens and providing simply that all residents of the United States should be taxable upon their entire net income and non-residents should be taxable only upon income from United States sources.

Even though Congress should not go so far and should continue to confine the exemption to foreign earned income, Congress should by all means eliminate the existing confusion and uncertainty as to

39 G. C. M. 9825 X-2 C.B. 146 ; McLarry v. Commissioner (C. C. A. 5th, 1929) 30 Fed. (2d) 789. U. S. Treas. Reg 103, \$19.25-2. 
whether the exemption is predicated on non-residence or simply on absence from the United States and should also eliminate the inequalities resulting from requiring that the non-residence or absence be for a fixed period of time during the taxable year. This could be achieved by according citizens exemption from tax on foreign earned income derived during the time they are non-residents of the United States and by defining "non-resident" as meaning any citizen who is absent from the country for other than temporary or transitory purposes.

Under either of the foregoing suggestions, difficulty would undoubtedly be experienced in determining whether citizens are residents or non-residents, but this should prove no more burdensome than in the case of aliens.

\section{CREDIT FOR FOREIGN INCOME TAXES}

Since 1928 provision has been made for allowing citizens and resident aliens credit for income taxes paid or accrued to foreign countries or to possessions of the United States. ${ }^{40}$ Citizens are allowed the credit for taxes paid or accrued to foreign countries and residents, both citizens and aliens, are allowed the credit for taxes paid or accrued to possessions of the United States without any requirement of reciprocity. Resident aliens, however, are allowed credit for taxes paid or accrued to foreign countries only if the state or country of which they are a citizen or subject imposes an income tax and either exempts citizens of the United States residing therein from the tax or allows such citizens a credit substantially similar to the credit allowed by our Act. ${ }^{43}$

The credit may be taken either in the year in which the foreign tax accrues or in the year in which it is paid. Although there is no limitation on the amount of income taxes paid or accrued to a foreign country which may be considered in computing the amount of the credit allowable, the amount allowable is subject to the following two limitations:

1. The credit in respect of the tax paid or accrued to any country may not exceed the same proportion of the tax against which the credit is taken as the taxpayer's net income from sources within the country bears to his entire net income; and

40 I. R. C. \$131. Credit is also allowed domestic corporations substantially to the same extent as in the case of citizens.

11 I. R. C. $\$ 131$ (a) and (b) ; U. S. Treas. Reg. 103, \$19.131-1. 
2. The total amount of the credit shall not exceed the same proportion of the tax against which the credit is taken as the taxpayer's net income from sources without the United States bears to his entire net income.

In lieu of claiming credit the taxpayer may at his option claim a deduction for the foreign taxes. The option may be exercised at any time prior to the expiration of the period for making a claim for refund or credit.

The credit provisions are far from being inspired and may be summarily criticized as follows:

1. If resident aliens are to be taxed on their world-wide net income to the same extent as citizens, they should in all fairness be allowed credit to the same extent. In any event, they should at least not be denied credit for taxes paid or accrued to other countries on income from sources therein simply because of the fortuitous circumstances that the country of which they are citizens or subjects does not happen to see fit to impose an income tax.

2. Although we tax non-resident aliens on income from sources within the United States and, accordingly, are at least equally responsible for any double taxation that results in those cases where such income is also taxed by the state or country of which the alien is a citizen or subject or in which he resides, we make no provision whatsoever for allowing them credit, but, instead, take the position that they must look only to the country of which they are a citizen or subject or in which they reside for relief. Although we should change our attitude in this respect and indicate a willingness to do our part in endeavoring to eliminate burdensome double taxation, we might properly condition allowance of credit to non-resident aliens by placing it on a reciprocal basis. ${ }^{42}$

3. The Act allows credit for any income taxes paid or accrued to a foreign country regardless of whether the income on which the taxes are computed is' taxable under our law. Thus, it would appear that a non-resident citizen who is exempt from tax on foreign earned income might nevertheless obtain credit against his United States tax on other income for any taxes paid the country where such foreign income is earned. ${ }^{43}$

42 For a discussion of the reasons why credit should not be allowed non-residents and why it may properly be placed on a reciprocal basis see Keesling, op. cit. supro note 3 , at 708 et seq.

$\$ 3$ Carstairs v. United States, supra note 38 , the Court reached a contrary conclusion on this point on the ground that under section 116 of the Internal Revenue Code 
4. In computing the extent to which credit may be taken, the Act permits the entire net income from sources within a foreign country to be taken into account, even though a portion of such net income may not be taxed by the foreign country. As a result a inuch larger credit may be allowed than is necessary to eliminate double taxation.

5. The law imposes a double limitation on the allowance of the credit. Not only may the credit for taxes paid or accrued to any particular foreign country not exceed that proportion of the United States tax which the net income from the foreign country bears to the total net income, but it may also not exceed that proportion of the United States tax which the net income froin all foreign countries bears to the total net income. This latter limitation is but little short of being barbaric. Under this provision if a taxpayer should sustain a loss in one foreign country in an amount equivalent to the income from another foreign country, he would be allowed no credit for in-

which provides for the exemption of foreign earned income, such exempt income is excluded from gross income. The Court reasoned that if the foreign income is excluded the ratio of foreign income to total income must necessarily be zero. Although the result is proper as a matter of policy the reasoning is fallacious and reflects an incorrect interpretation of the law. Simply because the foreign earned income is excluded under section 116 from the total income, it by no means follows that it is not net income from sources within a foreign country which should be taken into consideration and compared with the taxpayer's total net income for the year for the purpose of applying the formula outlined in section 131. Suppose, for instance, a non-resident citizen has $\$ 50,000$ net income from sources within the United States and also has $\$ 25,000$ earned income from England upon which he is required to pay an English tax. Although the $\$ 25,000$ English income would not be included in computing the taxpayer's total net income, provided it is exempt under section 116, it is still net income from sources within another country. Accordingly under the plain literal language of section 131 any English taxes paid thereon are allowable as a credit against the Umited States tax on the $\$ 50,000$ in the ratio which the $\$ 25,000$ bears to $\$ 50,000$.

14 A citizen taxpayer has a total net income of $\$ 20,000$ which consists of $\$ 10,000$ rental income froin property located in $X$ country, which is taxable there, and $\$ 10,000$ from personal services performed in such country, which is exempt from tax under the laws of such country. The Umited States tax, let us say, amounts to $\$ 6,000$, one-half of which is attributable to the rental income and one-half to the earned income. In order to eliminate double taxation the allowable credit need not exceed the tax attributable to the rental income or $\$ 3,000$. If the credit were limited to that proportion of the United States tax which the income taxed in the foreign country bears to the total net income, the inaximum credit would be limited to one-half of the Umited States tax and, accordingly, would not exceed the above fignre. Under the law, however, credit may be taken against that proportion of the Umited States tax which the exempt as well asthe taxable income from the foreign country bears to the total net income. Accordingly, in this example, credit would he allowred for the full amount of the foreign tax even though it should exceed $\$ 3,000$. As a consequence a portion of the United States tax on the earned income would be eliminated even though such income is not doubly taxed. 
come taxes required to be paid to the latter country and accordingly would be given no relief from oppressive double taxation.

6. Credit for foreign taxes paid or accrued on income for one particular year may be taken not only agamst the American taxes on the income for that same year but, if such taxes are paid in a later year, may in the alternative be taken as a credit against the American taxes for such later year, even though the income on which the American taxes for the later year are computed do not include any of the foreign income, the taxes on which are allowed as a credit. This provision not only gives rise to confusion and uncertainty as to how the various limitations should be applied but may frequently result in the allowance of a greater or lesser credit than should properly be allowed in order to eliminate double taxation. The credit should of course be strictly limited to the accrual basis and allowed only against the United States taxes on the same income which is taxed in the foreign country.

The credit provisions of the California Income Tax Act were carefully worked out to eliminate most of the foregoing objections. ti $^{\text {in }}$ They might well serve as a pattern for an extensive revision of the federal provisions.

\section{CONCLUSTON}

Although domicile is frequently an important factor in determining the ownership of income as, for imstance, whether it is separate or community, it has otherwise played a very minor role in federal income taxation, particularly for jurisdictional purposes. This is just as well simce the inflexible rule of domicile, which permits an individual to live in a country for long periods of time enjoying the benefits and protection of its laws without being domiciled there and which on the other hand, permits him to be absent from a country for similar periods of time and still retain his domicile, is at best an extremely unsatisfactory test of jurisdiction for the imposition of income taxes. As far as the jurisdictional scope of the tax is concerned, citizenship and residence have from the beginning been the keystones of the federal income tax. As between these two concepts the latter is to be preferred to the former since citizenship as a basis of jurisdiction is subject to much the same objections as domicile. It is to be hoped that

45 Cax. Personal Inc. Tax Act (1935) $\$ \$ 25$ (a) and (b) as amended by Cal Stats. 1937, p. 1855. For analysis and discussion of tbese provisions see Keesling, op. cil. supra note 3, p. 708 et seq. 
in time the distinctions between individuals who are taxable upon their entire income and those who are only taxable upon income from United States sources will be drawn more heavily on the basis of objective considerations such as presence within a country and the purposes for which they are there rather than on subjective intentions and loyalties. 